\title{
EFFECT OF FEEDING OLIVE BY-PRODUCTS ON CERTAIN BLOOD PARAMETERS AND SERUM ENZYME ACTIVITIES OF FATTENING RABBITS
}

\author{
V. RUPIĆ ${ }^{1}$, V. BOŽIKOV ${ }^{3}$, R. BOŽAC ${ }^{1}$, S. MUŽIC $^{1}$, N. VRANEŠIĆ ${ }^{2}$ and M. ĐIKIĆ ${ }^{1}$ \\ ${ }^{1}$ Faculty of Agriculture, University of Zagreb; Svetošimunska c. 25, 10000 Zagreb, \\ Croatia; ${ }^{2}$ PLIVA, Chemical and Pharmaceutical Works, Research and Development, \\ Zagreb, Croatia; ${ }^{3}$ Clinic Hospital Dubrava, Aleja Izviđača, Zagreb, Croatia
}

(Received January 5, 1998; accepted September 22, 1998)

\begin{abstract}
The effect of feeding different levels (10 and 20\%) of dehydrated olive cake pulp on certain blood parameters and on the catalytic activity of serum enzymes was studied in fattening rabbits. A total of 60 rabbits were divided into a control group (C) and two experimental groups $\left(E_{1}, E_{2}\right)$, each comprising 10 males and 10 females. Rabbits of Group $\mathrm{C}$ received no dehydrated olive cake pulp in their diet, while rabbits of Group $E_{1}$ and Group $E_{2}$ were fed $10 \%$ and $20 \%$ dehydrated olive cake pulp, respectively. After Day 56 of the experiment, blood samples were obtained by cardiac puncture and certain blood parameters as well as the catalytic activity of serum enzymes were determined. Following the experimental feeding period no significant differences were found between Group $\mathrm{C}$ and Groups $\mathrm{E}_{1}$ and $\mathrm{E}_{2}$ in red blood cell (RBC) and white blood cell (WBC) count, haemoglobin concentration and haematocrit value. Similarly, after 56 days of experimental fattening no significant differences were found between the control group and the experimental groups in the catalytic activity of the serum enzymes alkaline phosphatase (AP), aspartate aminotransferase (AST), gamma-glutamyltransferase (GGT), and lactate dehydrogenase $(\mathrm{LDH})$. However, Group $\mathrm{E}_{2}$ rabbits manifested a significantly higher alanine aminotransferase (ALT) activity in the serum than did rabbits of Group $E_{1}$. The results indicate that the inclusion of dehydrated olive cake pulp in the diet at the rate of $10 \%$ or $20 \%$ caused no changes in the investigated blood parameters and serum enzyme activities of fattening rabbits.
\end{abstract}

Key words: Hyla rabbits, feeding, olive cake pulp, blood parameters, serum enzyme activities

Olive cake is a by-product obtained in the process of extraction of olive oil from olives. Olive cultivation forms a part of fruit production in many countries around the world, being particularly prevalent in the Mediterranean region. In the mass cultivation of olives the oil extraction process yields considerable quantities of olive cake, which in some countries is used as cattle feed in the form of cake, whereas in other countries it is disposed of in the area around the oil-producing plant, thereby polluting the environment. 
RUPIĆ et al.

The composition of olive cake makes it a valuable feed source for various species of animals. Depending on the technological process employed in olive oil extraction, olive cake contains between 3.5 and $5 \%$ oil, 2.5 to $6 \%$ crude protein, as well as other nutrients (Manoukas et al., 1973; Vešnik et al., 1993, 1994; Rupić et al., 1997). Olive cake also contains large amounts (22-35\%) of crude fibre which, although in larger quantities is harmful to pigs and poultry, is necessary for and beneficial to ruminants and rabbits. Where the process of centrifugal separation is employed (Van Soest, 1975; Sansoucy, 1985), the resulting cake has high water content (47-53\%), and thus the cake either has to be drained or dried before it is added to animal fodder. Olives also contain the glycoside oleoropein, which has a roborant effect (Jakobs, 1951) and which, when added to olive cake, can improve the taste of fodder.

Although olive cake has been used as an animal feed for a long period of time, few research projects have so far concentrated on its effects. Most of the studies carried out to date focused on the use of olive cake in the feed of ruminants (Belibasakis, 1984; Nefzaoui and Vanbelle, 1984; O'Donovan, 1984; Boucqué and Fiemes, 1986). Belibasakis (1984) studied the nutritive effect of olive cake pulp (treated and untreated with $\mathrm{NaOH}$ ) on the quantity of milk, total dry matter, milk fat, proteins and lactose in milk, as well as on relations between organic acids in the rumen of Friesian cows. In one experiment, cows were fed 7.5 and $15 \%$ plain olive cake pulp, while in another trial they were fed the same percentages of olive cake pulp treated with $\mathrm{NaOH}$. None of the animals developed any illness. In both experiments investigating the effects of feed containing 7.5 and $15 \%$ olive cake pulp (both treated and untreated with $\mathrm{NaOH}$ ), no changes occurred in the quantity of milk, total dry matter, or lactose and proteins in milk. The author concluded that olive cake pulp could be used in the feed of dairy cows. O'Donovan (1984) conducted experiments with dehydrated olive cake pulp in the feed of calves $(130 \mathrm{~kg})$ and yearlings $(283 \mathrm{~kg})$. He established that only large quantities (30\%) of dehydrated olive cake pulp in the feed concentrate caused a reduction in the body weight of calves. Only few research projects have dealt with pigs (Rupić et al., 1997) and poultry (Rupić et al., 1993; Christaki et al., 1994). Rupić et al. (1997) established that fattening pigs fed meals containing 5 and $6 \%$ dehydrated olive cake pulp achieved a slightly higher growth rate and higher finishing weight as compared to pigs not fed olive cake pulp. In an experiment carried out in broiler chickens fed dehydrated olive cake pulp at an inclusion rate of $5 \%$ and $6 \%$, Rupić et al. (1993) established that after a 50-day fattening period chickens fed olive cake pulp weighed slightly less than those fed a diet free of olive cake pulp. No significant differences were detected in red blood cell (RBC) count, haemoglobin concentration or haematocrit level between chickens fed and those not fed olive cake pulp. In the available literature we could not find any data on the influence of feeding olive cake pulp on 
haematological and biochemical variables or on the catalytic activity of serum enzymes in ruminants, pigs and rabbits.

Hence, the aim of the present study was to establish the nutritive effect of high levels (10 and 20\%) of dehydrated olive cake pulp in rabbits on the basis of certain haematological variables and the catalytic activities of serum enzymes after a 56-day period of test feeding.

\section{Materials and methods}

Sixty ( 30 male +30 female) weaned, 30-day-old Hyla rabbits were used. The rabbits were divided into three groups, each group comprising 20 animals: a control group $(\mathrm{C})$ and two experimental groups $\left(\mathrm{E}_{1-2}\right)$. All rabbits were marked with numbers from 1 to 60 , tattooed on the right ear. Initial average body mass of Group C rabbits was $666.15 \pm 78.99 \mathrm{~g}$, while that of rabbits in the two experimental groups was $659.15 \pm 83.42 \mathrm{~g}\left(\mathrm{E}_{1}\right)$ and $648.25 \pm 82.27 \mathrm{~g}\left(\mathrm{E}_{2}\right)$. Analysis of variance showed that differences in the initial body weight of rabbits between the groups were not significant. Each group of rabbits was housed in five stainless steel cages, located in the same room and on the top of each battery. The room was air-conditioned with temperature maintained at 18 to $20{ }^{\circ} \mathrm{C}$ and relative humidity between 60 and $70 \%$. In order to decrease the risk of infection, all cages and equipment were treated with a chlorine disinfectant prior to the experiment.

The basic chemical composition of olive cake pulp is shown in Table 1.

Table 1

Chemical composition of olive cake pulp (\% in original matter)

\begin{tabular}{rccccccc}
\hline \multicolumn{7}{c}{ Basic chemical composition } \\
\cline { 2 - 5 } & Ash & $\begin{array}{c}\text { Crude } \\
\text { protein }\end{array}$ & $\begin{array}{c}\text { Crude } \\
\text { fat }\end{array}$ & $\begin{array}{c}\text { Crude } \\
\text { Fibre }\end{array}$ & NFE* & Ca & P \\
\hline $\begin{array}{r}\text { Fresh olive cake } \\
48.72\end{array}$ & 0.81 & 2.79 & 3.92 & 25.98 & 17.78 & 0.07 & 0.04 \\
$\begin{array}{r}\text { Dehydrated olive cake pulp } \\
1.95\end{array} \quad 1.56$ & 5.34 & 7.50 & 49.70 & 33.95 & 0.14 & 0.08 \\
\hline
\end{tabular}

${ }^{*} \mathrm{NFE}=$ nitrogen-free extract

Throughout the experiment, Group $\mathrm{C}$ rabbits received a feed containing no olive cake pulp, while those of Group $\mathrm{E}_{1}$ and Group $\mathrm{E}_{2}$ received a feed containing $10 \%$ and $20 \%$ dehydrated olive cake pulp, respectively. The composition of feed mixtures and their chemical analyses are shown in Table 2. 
Table 2

Ingredients and chemical composition of diets

\begin{tabular}{|c|c|c|c|}
\hline \multirow{2}{*}{ Ingredients ( $\%$ as fed $)$} & \multicolumn{3}{|c|}{ Groups of animals } \\
\hline & $\mathrm{C}$ (control) & $\mathrm{E}_{1}$ & $\mathrm{E}_{2}$ \\
\hline Dehydrated olive cake pulp & 0.00 & 10.00 & 20.00 \\
\hline Maize & 28.40 & 31.90 & 34.70 \\
\hline Barley meal & 5.00 & 3.00 & 3.00 \\
\hline Wheat middlings & 6.00 & 5.00 & 6.00 \\
\hline Soybean meal, expelled & 0 & 10.00 & 17.40 \\
\hline Sunflower meal, expelled & 18.50 & 11.00 & 8.00 \\
\hline Dehydrated alfalfa meal & 41.00 & 27.80 & 9.00 \\
\hline Dibasic calcium phosphate & 0 & 0 & 0.20 \\
\hline Limestone & 0.30 & 0.50 & 0.90 \\
\hline Sodium chloride & 0.30 & 0.30 & 0.30 \\
\hline Mineral-vitamin mix & 0.50 & 0.50 & 0.50 \\
\hline Total & 100.00 & 100.00 & 100.00 \\
\hline \multicolumn{4}{|l|}{ Analysis as fed, $\%$ in dry matter ${ }^{*}$} \\
\hline Dry matter & 88.10 & 88.81 & 88.76 \\
\hline Crude protein & 17.44 & 17.89 & 17.63 \\
\hline Crude fat & 3.30 & 3.46 & 4.20 \\
\hline Crude fibre & 15.31 & 15.97 & 14.93 \\
\hline $\mathrm{Ca}$ & 0.92 & 0.83 & 0.76 \\
\hline $\mathrm{P}$ & 0.65 & 0.55 & 0.53 \\
\hline
\end{tabular}

*Official methods were used throughout (A. O. A. C., 1984)

Table 3 presents the amino acid composition of the feed mixture and dehydrated olive cake pulp.

The rabbits were fed the above-described mixtures continuously throughout the 56-day experimental period. Olive cake pulp used in the experiment was obtained through the centrifugal separation process (Martilotti, 1983), in which oil was extracted from local varieties of olives grown on the island of Krk. Fresh olive cake, containing $48.72 \%$ water, was dried at a temperature of $35{ }^{\circ} \mathrm{C}$ to a water content of $2 \%$ and was then reduced to particles $2 \mathrm{~mm}$ in size in a hammer mill. All rabbits involved in the experiment were fed from automatic feeders. Water was provided ad libitum from automatic dispensers.

The microbiological examination of one gram of feed mix showed a germ count of 270,000, 22,000 and 49,000 for Group C, Group $E_{1}$ and Group $E_{2}$, respectively. In the same quantity of feed no salmonellae were found, while sulphite-reducing clostridia did not exceed 1000 in all mixtures used. One gram of control mixture showed a mould count (Aspergillus sp., Penicillium sp.) of 4000. The mould count was less than 1000 in Group $E_{1}$ and 2000 in Group $E_{2}$. 
Table 3

Amino acid composition of the feed mix $^{*}$ and dehydrated olive cake ${ }^{* *}$ used in the experiment ( $\mathrm{g} / 100 \mathrm{~g}$ original matter)

\begin{tabular}{|c|c|c|c|c|}
\hline Amino acids & $\mathrm{C}$ (control) & $E_{1}$ & $\mathrm{E}_{2}$ & $\begin{array}{l}\text { Dehydrated olive } \\
\text { cake pulp }\end{array}$ \\
\hline Methionine & 0.33 & 0.31 & 0.30 & 0.02 \\
\hline Lysine & 0.67 & 0.78 & 0.85 & 0.07 \\
\hline Threonine & 0.69 & 0.70 & 0.68 & 0.28 \\
\hline Arginine & 1.08 & 1.11 & 1.18 & 0.24 \\
\hline Glycine & 0.90 & 0.82 & 0.76 & 0.31 \\
\hline Histidine & 0.42 & 0.43 & 0.43 & 0.07 \\
\hline Phenylalanine & 0.89 & 0.87 & 0.85 & 0.27 \\
\hline Leucine & 1.36 & 1.38 & 1.36 & 0.42 \\
\hline Isoleucine & 0.80 & 0.80 & 0.77 & 0.23 \\
\hline Valine & 0.86 & 1.10 & 1.49 & 0.33 \\
\hline Serine & 0.69 & 1.04 & 1.36 & 0.29 \\
\hline Tyrosine & 0.51 & 0.65 & 0.79 & 0.06 \\
\hline
\end{tabular}

"Calculated data (Rhône Poulenc Animal Nutrition, 1989); ${ }^{* *}$ Amino acid composition by analysis

At the end of the experiment blood samples were obtained by cardiac puncture for haematological analyses. Prior to puncture the rabbits were anaesthetised with an intramuscular injection of ketamine hydrochloride, $50 \mathrm{mg} / \mathrm{kg}$ body weight (Makek et al., 1981). When narcosis was established, the rabbits were laid down in dorsal recumbency and secured to a board designed for the taking of blood samples. Blood was stored in Greiner test tubes with EDTA. Blood samples $(10 \mathrm{ml})$ were taken from all rabbits included in the experiment ( $5 \mathrm{ml}$ with EDTA and $5 \mathrm{ml}$ without EDTA was taken from each animal). Each sample was placed in a separate test tube and then used for the determination of haematological parameters including red blood cell (RBC) count, haemoglobin $(\mathrm{Hb})$ concentration, haematocrit (Hct) value and white blood cell (WBC) count. The catalytic activities of the following serum enzymes were determined with reagents and using a Technicon H-1 apparatus: alkaline phosphatase (AP; EC 3.1.3.1), aspartate aminotransferase (AST; EC 2.6.1.1), alanine aminotransferase (ALT; EC 2.6.1.2), gamma-glutamyltransferase (GGT; EC 2.3.2.2) and lactate dehydrogenase (LDH; EC 1.1.1.27).

The rabbits used in this study were maintained in facilities approved by the Croatian Association for the Accreditation of Laboratory Animal Care, and in accordance with current regulations and standards issued by the Croatian Ministry of Agriculture. (1989).

All statistical analyses were performed using the SAS GLM procedure 


\section{Results}

After 56 days of feeding the following mean body weights were achieved: $2322.00 \pm 197.46 \mathrm{~g}(\mathrm{C}), 2331.50 \pm 222.06 \mathrm{~g}\left(\mathrm{E}_{1}\right), 2397.50 \pm 187.69 \mathrm{~g}\left(\mathrm{E}_{2}\right)$. No significant differences in body weight were found between Group $\mathrm{C}$ and the experimental groups. The feed conversion ratio (FCR) was 4.13 in the control group, 4.01 in Group $E_{1}$ and 3.92 in Group $E_{2}$.

The haematological variables of Hyla rabbits after 56 days of feeding are shown in Table 4.

Table 4

Haematological variables of rabbits after Day 56 of the experiment $(n=20)$

\begin{tabular}{lrrr}
\hline & \multicolumn{3}{c}{ Group of animals } \\
\cline { 2 - 4 } & \multicolumn{1}{c}{$\begin{array}{c}\mathrm{C} \\
(\text { mean } \pm \mathrm{SD})\end{array}$} & \multicolumn{1}{c}{$\begin{array}{c}\mathrm{E}_{1} \\
(\text { mean } \pm \mathrm{SD})\end{array}$} & $\begin{array}{c}\mathrm{E}_{2} \\
(\text { mean } \pm \mathrm{SD})\end{array}$ \\
\hline $\mathrm{RBC}, 10^{12} / \mathrm{L}$ & $6.04 \pm 0.44$ & $5.98 \pm 0.35$ & $6.00 \pm 0.38$ \\
Haemoglobin, $\mathrm{g} / \mathrm{L}$ & $130.89 \pm 6.68$ & $129.12 \pm 6.79$ & $128.76 \pm 6.74$ \\
Haematocrit, $/ \mathrm{L}$ & $36.54 \pm 1.88$ & $36.74 \pm 1.81$ & $36.70 \pm 2.19$ \\
WBC, $10^{9} / \mathrm{L}$ & $8.51 \pm 2.75$ & $8.11 \pm 2.65$ & $8.27 \pm 2.41$ \\
\hline
\end{tabular}

There were no statistically significant differences in the RBC count either between the control $(\mathrm{C})$ and the experimental groups $\left(\mathrm{E}_{1-2}\right)$ or between the two the experimental groups.

Rabbits of Group C were found to have the highest haemoglobin level, although no statistically significant differences were found in that variable between the control and the experimental groups, or between the two experimental groups.

Like the RBC count, the haematocrit value was very similar in all groups. The differences found between Group $\mathrm{C}$ and the experimental groups in Hct value were statistically insignificant.

The WBC count was also comparable in all groups of rabbits, with differences between the groups being minimal and insignificant.

Catalytic enzyme activities in rabbit serum are shown in Table 5.

Rabbits in the two experimental groups showed a higher AP activity in the serum than those in Group $\mathrm{C}$, but no statistically significant differences were found in that regard between Group $\mathrm{C}$ and the experimental groups, or between the two experimental groups.

Rabbits in Group $\mathrm{E}_{2}$ showed higher serum AST activity than those in Groups $\mathrm{C}$ and $\mathrm{E}_{1}$, although the differences were insignificant. 
Table 5

Catalytic activity of enzymes AP, AST, ALT, GGT and LDH in the blood serum of Hyla rabbits at the end of the experiment $(\mathrm{U} / \mathrm{l})(\mathrm{n}=20)$

\begin{tabular}{lccc}
\hline & \multicolumn{3}{c}{ Group of animals } \\
\cline { 2 - 4 } & $\mathrm{C}$ & $\mathrm{E}_{1}$ & $\mathrm{E}_{2}$ \\
\hline Enzyme & $($ mean $\pm \mathrm{SD})$ & $($ mean $\pm \mathrm{SD})$ & $($ mean $\pm \mathrm{SD})$ \\
AP & $70.73 \pm 19.87$ & $76.00 \pm 15.52$ & $78.32 \pm 22.33$ \\
AST & $34.41 \pm 10.96$ & $34.11 \pm 12.60$ & $38.16 \pm 17.78$ \\
ALT & $44.23 \pm 10.21$ & $41.00 \pm 7.90^{\dagger}$ & $45.79 \pm 9.94^{\dagger}$ \\
GGT & $5.96 \pm 1.68$ & $5.84 \pm 1.54$ & $6.58 \pm 1.80$ \\
LDH & $526.00 \pm 147.27$ & $524.26 \pm 176.69$ & $479.21 \pm 170.43$ \\
\hline
\end{tabular}

${ }^{\dagger}$ Significant difference $(\mathrm{P}<0.05)$ in average catalytic activity between experimental groups

The highest serum ALT activity was found in Group $\mathrm{E}_{2}$ rabbits $(45.79 \pm$ $9.94 \mathrm{U} / 1)$, and the lowest in Group $\mathrm{E}_{1}$ rabbits $(41.00 \pm 7.90 \mathrm{U} / \mathrm{l})$. The difference was statistically significant $(\mathrm{P}<0.05)$. However, there were no statistically significant differences in ALT activity between rabbits in Group $\mathrm{C}$ and those in the two experimental groups.

Serum GGT activity was roughly equal in all groups, the differences established being minimal and statistically insignificant.

The highest LDH activity was found in Group $\mathrm{C}$ rabbits and the lowest in rabbits of Group $\mathrm{E}_{2}$, although the differences between the two experimental groups were not statistically significant.

\section{Discussion}

On the basis of the achieved body weights it can be established that dehydrated olive cake pulp added to the feed at two different inclusion levels had no significant influence on the finishing body weight of fattening rabbits. The FCR was similar in all groups, demonstrating that different levels of dehydrated olive cake pulp had no influence on the FCR throughout the 56-day fattening period.

Following the 56-day experimental period the RBC count was very similar in Group C rabbits and in rabbits of the experimental groups, which indicates that, at the levels (10\% and $20 \%)$ added to the feed, dehydrated olive cake pulp had no influence on erythropoiesis in fattened rabbits.

After the 56-day feeding period, Group $\mathrm{C}$ rabbits showed an insignificantly higher haemoglobin concentration than those in the two experimental 
RUPIĆ et al.

groups, which implies that the $10 \%$ and $20 \%$ inclusion levels of dehydrated olive cake pulp in the feed mix had no influence on $\mathrm{Hb}$ synthesis.

Like the RBC count, the haematocrit value was also very similar in Group C rabbits and in those of the two experimental groups, indicating a lack of influence exerted by dehydrated olive cake on that variable.

The similar values of WBC count found in all groups suggest that the dehydrated olive cake pulp had no influence on leukopoiesis.

In all groups, the RBC and $\mathrm{WBC}$ counts as well as the $\mathrm{Hb}$ and Hct levels were similar to the values published as physiological for rabbits by Kolb (1962), Spörri and Stünzi (1969), Scheunert and Trautmann (1987), Bortolotti et al. (1989), McLaughlin and Fish (1994) and Rupić et al. (1991, 1996).

From the above results it can be concluded that dehydrated olive cake pulp fed at a level of $10 \%$ and $20 \%$ had no influence on erythropoiesis, leukopoiesis and on the $\mathrm{Hb}$ and Hct levels. In other words, it was not detrimental to the health of animals during the 56-day experimental fattening period.

The lowest serum AP activity was found in Group C rabbits, a higher level was established in Group $\mathrm{E}_{1}$, and the highest in Group $\mathrm{E}_{2}$. However, the differences found between the groups were not statistically significant. Hence, it can also be concluded that the $10 \%$ and $20 \%$ dietary levels of dehydrated olive cake pulp caused an insignificant rise in AP activity in the serum of rabbits during the 56-day feeding period. It would be of considerable practical value to continue feeding the rabbits with the same levels of dehydrated olive cake pulp in fodder mixes (for several months or even years) and to monitor the influence of that feed component on serum AP activity. The values of AP activity found in this study fully correspond to those quoted as physiological for rabbits by Grötsch and Hajdu (1979), Lindena and Trautschold (1986), and Hewit et al. (1989). However, the values found by us are higher than those reported by Dabew et al. (1976) and Yu et al. (1979), and lower than those published by Liker et al. (1998).

After the 56-day experimental period, Group $\mathrm{E}_{2}$ rabbits had higher serum AST activity than rabbits in Groups $\mathrm{C}$ and $\mathrm{E}_{1}$, although the differences were not statistically significant. Thus, at a dietary inclusion rate of $10 \%$ or $20 \%$ dehydrated olive cake pulp caused no significant changes in serum AST activity.

Changes were observed in serum ALT activity in rabbits fed mixtures containing dehydrated olive cake pulp ( $E_{1}$ and $E_{2}$ mixtures). Rabbits in Group $E_{1}$ showed a lower, and rabbits in Group $\mathrm{E}_{2}$ a higher, serum AST activity in relation to those in Group C. It is interesting to note that rabbits fed $10 \%$ dehydrated olive cake pulp had a significantly lower ALT activity than those fed $20 \%$.

Serum AST and ALT activities of rabbits in all groups are in the physiological range reported for rabbits by Kozma et al. (1974). They are higher than the values reported by Friedel and Mattenheimer (1970), Schievelbein et al. (1970), Grötsch and Hajdu (1971), Dabew et al. (1976), Lindena and Traut- 
schold (1986) and Liker et al. (1998), but lower than those found by Lepitzki and Woolf (1991). The slightly higher AST and ALT values of rabbits included in this experiment were due to the slight haemolysis that occurred during the taking of blood samples, rather than to the nutritive influence of dehydrated olive cake pulp added to the feed.

Serum GGT activity was roughly equal in all groups of rabbits, except that rabbits of Group $\mathrm{E}_{2}$ showed higher GGT activity than those in Group C and Group $\mathrm{E}_{1}$, although these differences were not statistically significant. It can therefore be concluded that consumption of feed containing different levels of dehydrated olive cake pulp caused no significant changes in serum GGT activity of rabbits after the 56-day period of experimental fattening. The GGT activities found in all groups of rabbits correspond to the values reported by Liker et al. (1998), and are higher than those described by Yu et al. (1979), Lindena and Trautschold (1986), and Lepitzki and Woolf (1991).

Rabbits of both experimental groups had lower serum LDH activity than the control rabbits, although the differences found were not statistically significant, suggesting that the feeding of dehydrated olive cake pulp had no effect on serum LDH activity. The serum LDH activity found in all groups of rabbits included in this experiment was higher than the values reported by Friedel and Mattenheimer (1970), Schievelbein et al. (1970), Dabew et al. (1976), Yu et al. (1979), Lindena and Trautschold (1986) and Hewit et al. (1989), they were equal to values published by Grötsch and Hajdu (1971), and lower than those reported by Liker et al. (1998). That high level of serum LDH activity found in all groups of rabbits in this experiment was probably the result of a mild haemolysis that occurred during the taking of blood samples. The procedure of taking blood from the heart, which caused a minor damage to the myocardial cells, also contributed to the high serum LDH activity.

On the basis of the haematological variables and the catalytic activities of serum enzymes it can be concluded that dehydrated olive cake pulp, when added to the feed at a level of $10 \%$ or $20 \%$, exerted no harmful effect on the haematopoietic system or on the catalytic activity of serum enzymes. In other words, it was not detrimental to the health of rabbits during the 56-day fattening period.

\section{References}

A. O. A. C. (1984): Official Methods of Analysis (14 $4^{\text {th }}$ ed.). Association of Official Analytical Chemists. Arlington, VA, USA.

Belibasakis, N. G. (1984): Olive cake pulp as feed for lactating cows. World Rev. Anim. Prod. 20, 7-10.

Bortolotti, A., Castelli, D. and Bonati, M. (1989): Hematology and serum chemistry values of adult, pregnant and newborn New Zealand rabbits (Oryctolagus cuniculus). Lab. Anim. Sci. 39, 437-439. 
Boucqué, Ch. V. and Fiemes, L. O. (1986): Vegetable by-products of agro-industrial origin. EAAP Working Group. Revised draft. Brussels, June 1986. Chapter 2.4.1, pp. 1-51.

Christaki, E., Yannakopoulos, A. L., Florou-Paneri, P., Kufidis, D. and Georgopoulu, I. E. (1994): Effect of olive pulp on the performance of laying hens. Proceedings of $9^{\text {th }}$ European Poultry Conference, Glasgow, UK, August 7-12, Vol. 1.

Dabew, D., Mahlberg, F. A. and Strauck, H. (1976): Enzymaktivitäten in Serum von Kaninchen und Ratten-Referenzwerte und Tagesschwankungen. J. Clin. Chem. Clin. Biochem. 14, 561-567.

Friedel, R. and Mattenheimer, H. (1970): Release of metabolic enzymes from platelet dusting blood clotting of man, dog, rabbit and cat. Clin. Chim. Acta 30, 37-46.

Grötsch, H. and Hajdu, P. (1971): Automatische Bestimmung von Enzymaktivitäten in tierischen Seren mit dem Reaction Rate Analyzer 8600. Z. Klin. Chem. Klin Biochem. 10, 334-337.

Hewit, C. D., Innes, D. J., Savory, J. and Wills, M. R. (1989): Normal biochemical and hematological values in New Zealand White rabbits. Clin. Chem. 35, 1777-1779.

Jakobs, M. B. (1951): The Chemistry and Technology of Food and Food Products. Interscience Publishers, New York, pp. 2317-2321.

Kolb, E. (1962): Lehrbuch der Physiologie der Haustiere. VEB Gustaf Fischer Verlag, Jena, pp. $388-405$.

Kozma, C., Macklin, W., Cummins, L. M. and Mauer, R. (1974): The anatomy, physiology and biochemistry of the rabbit. In: Weisbroth, S. H., Flatt, R. E. and Kraus, A. L. (eds) The Biology of the Laboratory Rabbit. Academic Press, New York, pp. 50-72.

Lepitzki, D. and Woolf, A. (1991): Hematology and serum chemistry of cottontail rabbits of southern Illinois. J. Wildl. Dis. 27, 643-649.

Liker, B., Božac, R., Husdžinović, I., Mužic, S., Bioćina, B., Tumpić, A. and Rupić, V. (1998): Activity of some enzymes in the blood plasma of Hyla rabbits fed various proportions of substrate from the production of the Pleurotus pulmonarius mushroom. Acta Vet. Brno 67, 25-34.

Lindena, J. and Trautschold, B. (1986): Catalytic enzyme activity concentration in plasma of man, sheep, dog, cat, rabbit, guinea pig, rat and mouse. J. Clin. Chem. Clin. Biochem. 24, 11-18.

Makek, Z., Tomašković, A. and Cergolj, M. (1981): Use of Ketalar in the laparotomy, ovariotomy and ovariohysterectomy of female rabbits (in Croatian). Vet. Arhiv 51 (Suppl.), 90-91.

Manoukas, G., Mazamenos, B. and Patrinon, M. (1973): Amino acids composition of 3 variations of olives. J. Agric. Food Chem. 21, 215-216.

Martilotti, F. (1983): Use of olive by-products in animal feeding in Italy. Animal Production and Health Division, Rome.

McLaughlin, R. M. and Fish, R. E. (1994): Clinical Biochemistry and Hematology. In: Manning, P. J., Ringler, D. H. and Newcomber, C. E. (eds) The Biology of the Laboratory Rabbit. Academic Press, Inc., New York-London, pp. 111-128.

Nefzaoui, N. and Vanbelle, M. (1986): Effects of feeding alkali-treated olive cake on intake, digestibility and rumen liquor parameters. Anim. Feed Sci. Technol. 14, 139-149.

O'Donovan, P. B. (1984): Feeding trial results with olive pulp. World Rev. Anim. Prod. 20, 7-14.

Rhône Poulenc Animal Nutrition (1989): Nutrition Guide. Feed formulation with digestible amino acids. First edition, pp. 1-23.

Rupić, V., Božac, R., Mužic, S., Rogina, Ž., Vranešić, N. and Jergović, I. (1991): Effect of spent substrate used for the commercial production of Pleurotus pulmonarius fungi on some haematological and biochemical blood parameters of Chinchilla rabbits (in Croatian). Vet. Glasnik 45, 17-23.

Rupić, V., Huskić, Lina, Vranešić, N., Božac, R., Stipić, N. and Vešnik, F. (1993): Olive cake in fattening chickens (in Croatian). Krmiva 34, 175-184.

Rupić, V., Božac, R., Mužic, S., Romić, Ž. and Liker, B. (1996): Haematological values of Hyla rabbits fed different levels of by-product arising from the propagation of Pleurotus pulmonarius. Acta Vet. Hung. 44, 75-83. 
Rupić, V., Jerković, I., Božac, R., Glowattzky, Dunja, Mužic, S. and Hrabak, V. (1997): Olive byproducts in pig fattening. Acta Vet. Hung. 45, 53-66.

Sansoucy, R. (1985): Olive by-products for animal feed. FAO, Animal Production and Health Division, Rome. Paper 43, 8-15.

SAS Institute (1989): SAS User Guide, Version 6 (fourth ed.) Volumes 1-2. SAS Institute Inc., Cary, N.C.

Scheunert, A. and Trautmann, A. (1987): Lehrbuch der Veterinär-Physiologie. 7. Aufl. Paul Parey, Berlin und Hamburg. pp. 84-85, 160-207.

Schievelbein, H., Londong, W., Londong, G., Grumbach, H. and Remplik, V. (1970): Nicotine and arteriosclerosis. Z. Klin. Chem. Klin. Biochem. 8, 190-196.

Spörri, H. and Stünzi, H. (1969): Pathophysiologie der Haustiere. Paul Parey, Berlin and Hamburg. pp. $1-67$.

Van Soest, P. J. (1975): Physico-chemical aspects of fibre digestion. In: McDonald, I. W. and Warner, A. C. I. (eds) Digestion and Metabolism in the Ruminant. University of New England, Armidale, pp. 351-365.

Vešnik, F., Rupić, V. and Černy, Tajana (1993): Technological value of crude olive cakes from the Croatian region of Istra (in Croatian). $9^{\text {th }}$ International Symposium of Technologies for Drying and Storing. Zbornik radova, pp. 154-162.

Vešnik, F., Rupić, V. and Černy Tajana (1994): Olive cake as an animal feed component (in Croatian). $10^{\text {th }}$ International Symposium of Technologies for Drying and Storing. Zbornik radova, pp. 200-206.

Yu, L., Pragay, D. A., Chang, D. and Wicher, K. (1979): Biochemical parameters of normal rabbit serum. Clin. Biochem. 12, 83-87. 